\title{
Effect of Oilcakes on the Management of Wilt Disease of Tomato Caused by Fusarium oxysporum f. sp. lycopersici
}

\author{
M. Dhivya*, M. Muthamilan, R. Kalaivanan, K. Devrajan and C. Chinnaiah \\ Department of Plant Pathology, Agricultural College and Research Institute, \\ Madurai - 625104 Tamil Nadu, India \\ *Corresponding author
}

\section{A B S T R A C T}

\begin{tabular}{|l|}
\hline Key w ord s \\
$\begin{array}{l}\text { Tomato, Fusarium } \\
\text { oxysporum f. sp. } \\
\text { lycopersici, } \\
\text { Wilt, Oil cake. }\end{array}$ \\
\hline Article Info \\
\hline $\begin{array}{l}\text { Accepted: } \\
17 \text { October } 2017 \\
\text { Available Online: } \\
10 \text { December } 2017\end{array}$ \\
\hline
\end{tabular}

\section{Introduction}

Tomato (Solanum lycopersicum L.) is one of the most important solanaceous crops grown throughout the world, and commonly grown in Tamil Nadu. It is one of the most and popular vegetables being second after potato in terms of food value but ranks first in terms of processing value (Dutta et al., 2013). All over India vegetable cultivation reaches 9205 thousand ha and 162187 metric tonnes (Mt) of production, in which tomato is being cultivated in about 879.63 thousands ha and the production is $18226.64 \mathrm{Mt}$ with a productivity of $20.7 \mathrm{Mt} / \mathrm{ha}(\mathrm{NHB}, 2013)$. The area of tomato cultivation in Tamil Nadu is 25,370 hectares with production of 328.2 tonnes per hectare. The major tomato growing districts in Tamil Nadu are Dharmapuri which occupies rank first followed by Krishnagiri, Salem, Theni, Dindigul and Coimbatore (Anonymus, 2009).

The tomato fruit is responsible for "red revolution" in agriculture and it may also be called as "poor man's orange" in India and "love of apple" in England. It served as important source of vitamin $\mathrm{A}$ and $\mathrm{C}$, minerals, some dietary fibre, a little protein and much water. Several successful attempts have been made for the integration of chemical and biological method of plant disease control. Jatav and Kusum Mathur (2005) reported that neem oil and neem cake extract have been found to be effective against several plant pathogens. 


\section{Materials and Methods}

Required quantity of each oilcake was made into powder separately. It was soaked in sterile distilled water @ one gram in $1.25 \mathrm{ml}$ of water separately and kept overnight. Then the material was ground using pestle and mortar and filtered through a muslin cloth and the filtrate was centrifuged at $10000 \mathrm{rpm}$ for 15 min. The supernatant served as the standard extract solution (100\%) (Dubey and Patel, 2000)

The efficacy of oil cake extract was tested against Fusarium oxysporum using poisoned food technique (Schmitz, 1930). The freshly prepared PDA was distributed @ 50ml medium per conical flask. Aqueous extracts oil cake $5 \mathrm{ml}$ was mixed with $50 \mathrm{ml}$ of PDA medium to obtain 5 per cent and sterilized. The sterilized PDA medium (15 ml per Petri dish) was poured on sterilized Petri dish and then allowed to solidify. A nine mm mycelial disc of Fusarium oxysporum was transferred from actively growing culture and placed at the centre of the Petri dish and incubated at room temperature. The PDA medium without extract of oilcake served as control. The radial growth $(\mathrm{cm})$ of Fusarium oxysporum was recorded after seven days of inoculation.

Table.1 Efficacy of extracts of five oil cake extract against the growth of Fusarium oxysporum f. sp. lycopersici in vitro

\begin{tabular}{|c|l|c|c|c|}
\hline S. No. & \multicolumn{1}{|c|}{ Organic amendments } & Conc. $(\boldsymbol{\%})$ & $\begin{array}{c}\text { Mycelial growth } \\
\text { at 10 DAI (cm)* }\end{array}$ & $\begin{array}{c}\text { Growth reduction } \\
\text { over control (\%) }\end{array}$ \\
\hline 1. & Mahua cake (Madhuca longifolia) & 10 & 2.13 & 76.33 \\
\hline 2. & Neem cake (Azadirachta indica) & 10 & 1.73 & 80.77 \\
\hline 3. & Gingelly cake (Sesamum indicum) & 10 & 3.10 & 65.56 \\
\hline 4. & Cotton cake (Gosspium hirsutum) & 10 & 3.20 & 64.44 \\
\hline 5. & Coconut cake (Cocos nucifera) & 10 & 3.46 & 62.11 \\
\hline 6. & Control & - & 9.00 & 0.00 \\
\hline \multicolumn{7}{r|}{$\mathbf{C D}(\mathbf{P}=\mathbf{0 . 0 5})$} & $\mathbf{0 . 1 2}$ & - \\
\hline
\end{tabular}

Plate.1 Efficacy of extracts of five oil cake extract against the growth of Fusarium oxysporum f. sp. lycopersici in vitro

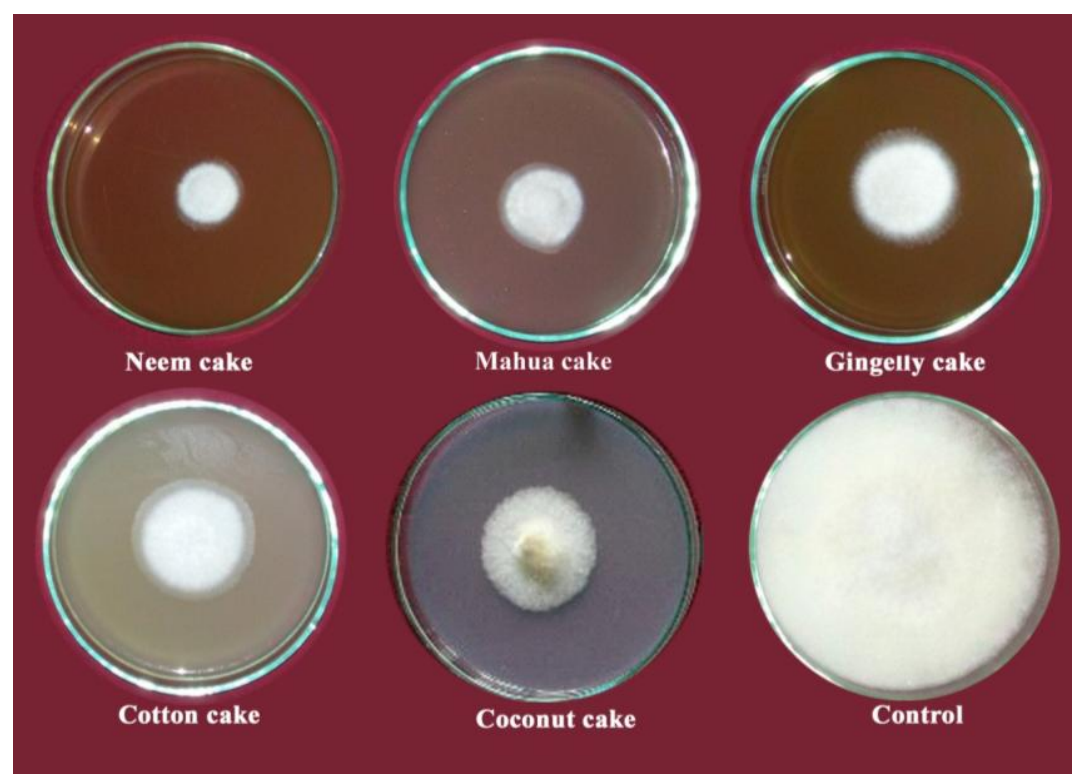




\section{Results and Discussion}

The result on the efficacy of extracts of five oil cake extract against the growth of Fusarium oxysporum f. sp. lycopersici are furnished in the Table 1.

The result showed that neem cake extract $(10 \%)$ recorded the maximum (80.77) per cent reduction of mycelial growth over control followed by Mahua cake (10\%) extract (76.33) per cent. The minimum (62.11) per cent reduction was observed in coconut cake. Padmodaya et al., (1999) reported that maximum inhibition of the growth of $F$. solani was recorded in neem cake 59.29 per cent next best in the order of merit was Mahua cake 52.61 per cent.

\section{References}

Anonymus, 2009. Science Reporter.In vitro and in silica studies on bio control agent of bacterial strains against Fusarium oxysporum f. sp. lycopersici. Research in Biotechnology, 3: 22-31.
Dubey, S.C. and Patel, B. 2000. In vitro evaluation of some oil cakes and plant extracts against Thanetophorus cucumeris, Gliocladium virens and Trichoderma viride. J. Mycol Pl. Pathol., 30: 411-413

Dutta, R., S. Chandra and S.V. Ngachan.2013.Evolution of tomato genotypes against bacterial wilt (Ralstonia solanacearum) under mid hill conditions. Indian Phytopath. 66(1): 96-97.

Jatav, R.S. and KusumMathur. 2005. Bioagents and neem based seed treatment for management of root rot complex in cluster bean. Indian phytopath, 58:235.

NHB.gov.in

Padmodaya, B. and Reddy, H.R. 1999. Effect of organic amendments on seedling disease of tomato caused by Fusarium oxysporum f. sp. lycopersici. J. Mycol. Pl Pathol. 29:38-41.

Schmitz, H. 1930. Poisoned food technique Industrial and Engineering chemistry Analyst, 2:361.

\section{How to cite this article:}

Dhivya, M., M. Muthamilan, R. Kalaivanan, K. Devrajan and Chinnaiah, C. 2017. Effect of Oilcakes on the Management of Wilt Disease of Tomato Caused by Fusarium oxysporum f. sp. lycopersici. Int.J.Curr.Microbiol.App.Sci. 6(12): 2138-2140.

doi: https://doi.org/10.20546/ijcmas.2017.612.245 